Supporting Information

The Supporting Information is available free of charge on the ACS Publications website.

Experimental procedures and data

\title{
Exposure of Human Lung Cells to Polystyrene Microplastics Significantly Retards Cell Proliferation and Triggers Morphological Changes
}

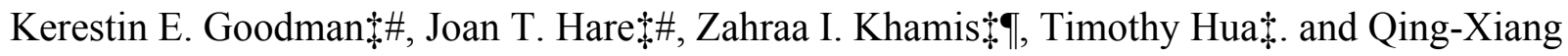
Amy Sang $\sharp \S^{*}$

†Department of Chemistry and Biochemistry, Florida State University, Tallahassee, FL 32306

§Institute of Molecular Biophysics, Florida State University, Tallahassee, FL 32306

IDepartment of Chemistry and Biochemistry, Lebanese University, Faculty of Sciences, HadathBeirut, Lebanon

$\underline{\text { Table of Contents }}$

$\underline{\text { Page }}$

Table S1. Conversions of $\mu \mathrm{g} / \mathrm{ml}$ to particles $/ \mathrm{ml}$ for different sizes of microplastics $\quad$ S2

Table S2. Characteristics of microplastics from Material Data Sheet S3

Figure S1. Live cell images showing differences in cell morphology at 60hours $\quad$ S4

Figure S2. Live cell images of A549 cells at 72hours post exposure to PS-MPs S5

$\begin{array}{ll}\text { Figure S3. Metabolic activity/cell } & \text { S6 }\end{array}$

$\begin{array}{ll}\text { Figure S4. Flow cytometry controls and settings for Calcein A-M staining } & \text { S7 }\end{array}$

Figure S5. Flow cytometry controls and gate settings for Ki 67 antibody experiments $\quad$ S8

Figure S6. Flow cytometry of 1micron and 10micron PS-MP particles alone S9

Figure S7. Additional confocal microscopy images of A549 cells exposed and unexposed to 1 micron green fluorescent PS-MPs

Table S3. Cytoskeletal and morphological features 


\begin{tabular}{|c|c|c|c|c|c|c|c|c|c|}
\hline \multirow[b]{2}{*}{ Size } & \multirow{2}{*}{$\begin{array}{l}\text { Units of } \\
\text { measurement } \\
\mu \mathrm{g} / \mathrm{ml}\end{array}$} & \multirow[b]{2}{*}{0.05} & \multirow[b]{2}{*}{1.00} & \multicolumn{4}{|c|}{ Conversions of $\mu \mathrm{g} / \mathrm{ml}$ to particles $/ \mathrm{ml}$} & \multirow[b]{2}{*}{75.00} & \multirow[b]{2}{*}{100.00} \\
\hline & & & & 5.00 & 10.00 & 25.00 & 50.00 & & \\
\hline 1 micron & Particles/ml & $7.85 \times 10^{4}$ & $1.57 \times 10^{6}$ & $7.85 \times 10^{6}$ & $1.57 \times 10^{7}$ & $3.93 \times 10^{7}$ & $7.85 \times 10^{7}$ & $1.18 \times 10^{8}$ & $1.57 \times 10^{8}$ \\
\hline 10 micron & Particles/ml & $8.20 \times 10^{1}$ & $1.64 \times 10^{6}$ & $8.20 \times 10^{3}$ & $1.64 \times 10^{4}$ & $4.10 \times 10^{4}$ & $8.20 \times 10^{4}$ & $1.23 \times 10^{5}$ & $1.64 \times 10^{5}$ \\
\hline
\end{tabular}

Table S1. Conversions of $\mu \mathrm{g} / \mathrm{ml}$ to particles/ml for different sizes of microplastics. Concentrations of PS-MPs in this paper were measured in $\mu \mathrm{g} / \mathrm{ml}$, following the generally accepted standard in the field of Toxicology and Environmental Toxicology. However, since microplastics are particles and not uniform solutions, particles/ml may be a better description of the quantities to which a cell or tissue is exposed. Table S1 provides a direct conversion of the $\mu \mathrm{g} / \mathrm{ml}$ units as used in this paper, to particles per $\mathrm{ml}$ for each of the particle sizes. 10micron diameter particles are 10 times the width of 1 micron particles, but on a volume basis are approximately 1000 times larger. B) As seen in the second and third lines of the table, when particle size is discounted and only particle concentration is considered, our work covered a concentration range of 82 particles per $10 \mathrm{~cm}^{2}$ dish, to a high of approximately $2 \times 10^{6}$ particles per $10 \mathrm{~cm}^{2}$ dish, or 5 orders of magnitude without showing major concentration effects. The near identical concentrations for particles $/ \mathrm{ml}$ for the 1 micron and 10micron are highlighted (near the end of the 10micron series and the start of the 1micron series) to emphasize the overlap between the ranges of these two sets of concentrations. 


\begin{tabular}{|c|c|c|c|c|c|c|c|c|c|}
\hline $\begin{array}{c}\text { Size } \\
(\boldsymbol{\mu \mathbf { m }})\end{array}$ & Polymer & Color & Surface & Fluorescence & $\begin{array}{c}\text { Target } \\
\text { Mean } \\
\text { Diameter } \\
(\boldsymbol{\mu m})\end{array}$ & $\begin{array}{c}\text { Actual } \\
\text { Mean } \\
\text { Diameter } \\
(\boldsymbol{\mu m})\end{array}$ & $\begin{array}{c}\text { Standard } \\
\text { Deviation } \\
(\boldsymbol{\mu m})\end{array}$ & $\begin{array}{c}\text { Density } \\
\text { of } \\
\mathbf{P o l y m e r} \\
\left(\mathbf{g} / \mathbf{c m}^{\mathbf{3}}\right)\end{array}$ & $\begin{array}{c}\text { Number of } \\
\text { Spheres } \\
(\mathbf{p e r} \mathbf{m L})\end{array}$ \\
\hline 10 & Polystyrene & None & None & None & 10 & 10.350 & 1.232 & 1.05 & $1.64 \times 10^{7}$ \\
\hline 1 & Polystyrene & None & None & None & 1 & 1.051 & 0.199 & 1.05 & $1.57 \times 10^{10}$ \\
\hline 1 & Polystyrene & None & None & Green & 1 & 1.250 & 0.230 & 1.05 & $9.31 \times 10^{9}$ \\
\hline
\end{tabular}

Table S2. Characteristics of microplastics from Material Data Sheet provided by the vendor. All polystyrene microplastics were purchased from Degradex. 

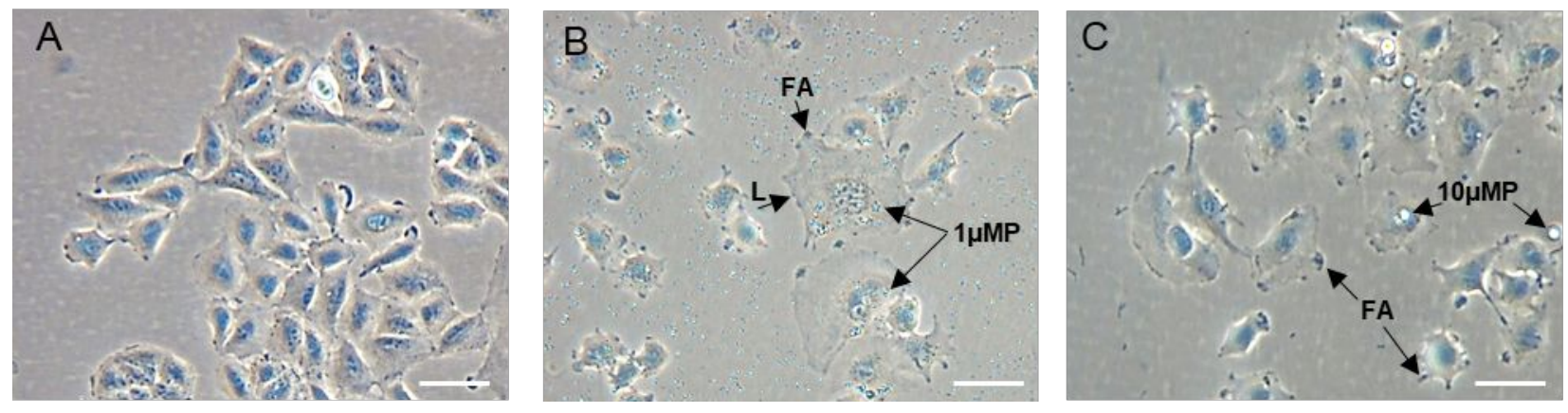

Figure S1. Additional live cell images showing differences in cell morphology at 60hours. Photographs were taken at 100X (A) Control cells, (B) 1micron exposed cells, (C) 10micron exposed cells. When the photographs are expanded, 1micron PS-MPs can be seen more clearly inside the A549 cell and in some cells they appear to be organized in a circular fashion. In 10micron exposed cells, the microplastic particles are not internalized in the cells. The lamellar edges can be seen in these phase contrast images and the dark non-refractile focal adhesions are clearly visible where the lamellipodia are advancing in both 1 micron and 10micron PS-MPs exposed cells. These morphological characteristics are specific to the exposed cells and are not seen in the unexposed A549 control cells. Filopodia (FA), Lamellipodia (L), 1micron (1 $\mu \mathrm{MP})$, and 10 micron $(10 \mu \mathrm{MP})$. Scale bars are 50micron. 

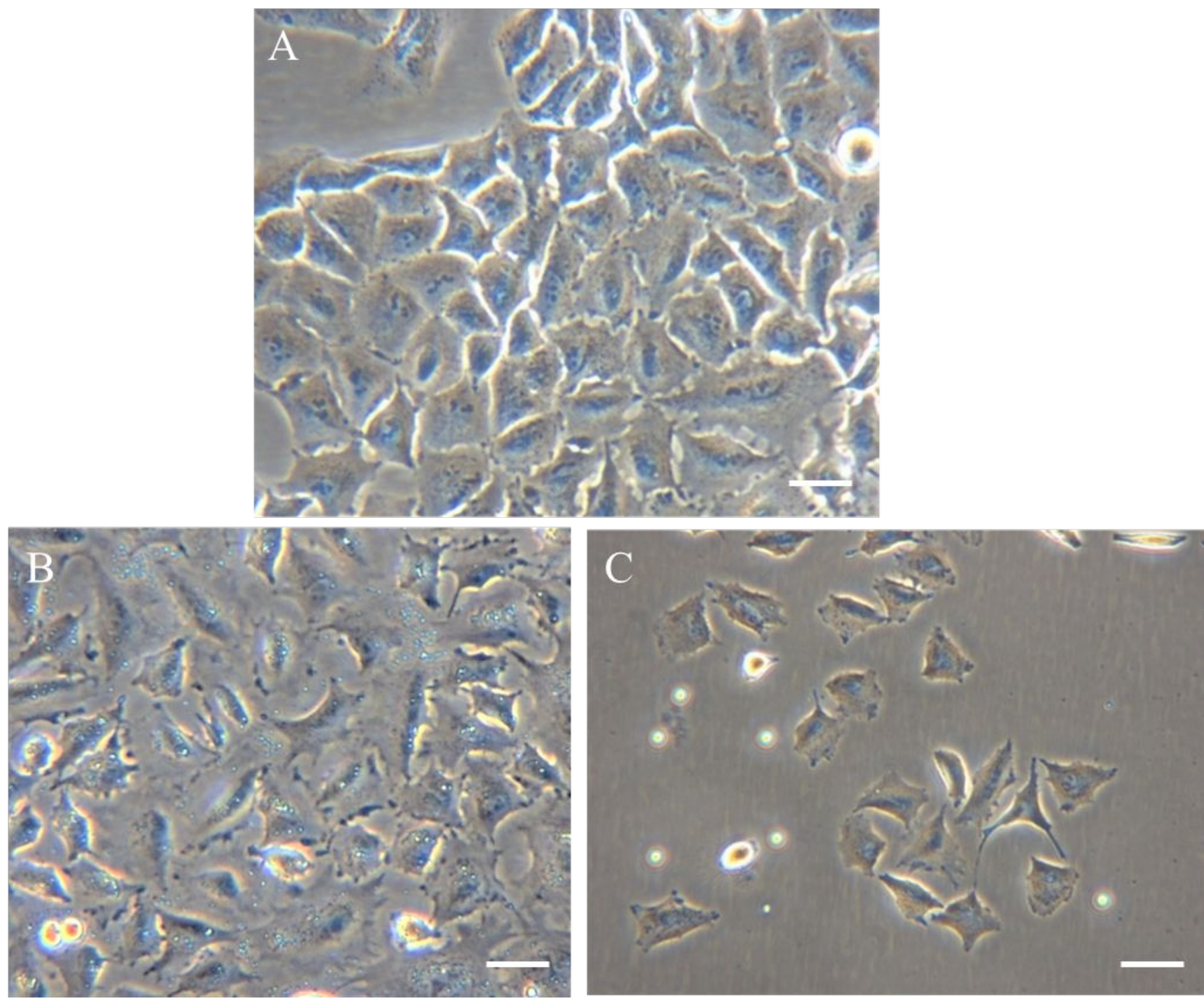

Figure S2. Phase contrast images of live A549 cells at 72hours post exposure to PS-MPs. A) Control, unexposed cells after 72 hours of continued culture, B) and C) cells exposed to $5 \mu \mathrm{g} / \mathrm{ml}$ PSMPs for the same 72 hour period. B) 1micron particles and C) 10micron particles. B) photograph was taken in a dense area of the plate, while C) photograph was taken in a sparse area of the plate. Photographs were taken at 200X. In C) six bluish hued 10micron particles can be seen and 2 larger golden hued mitotic cells. In B) when image is expanded, most cells can be seen to have multiple bright 1 micron particles within. Scale bars are 50 microns. 


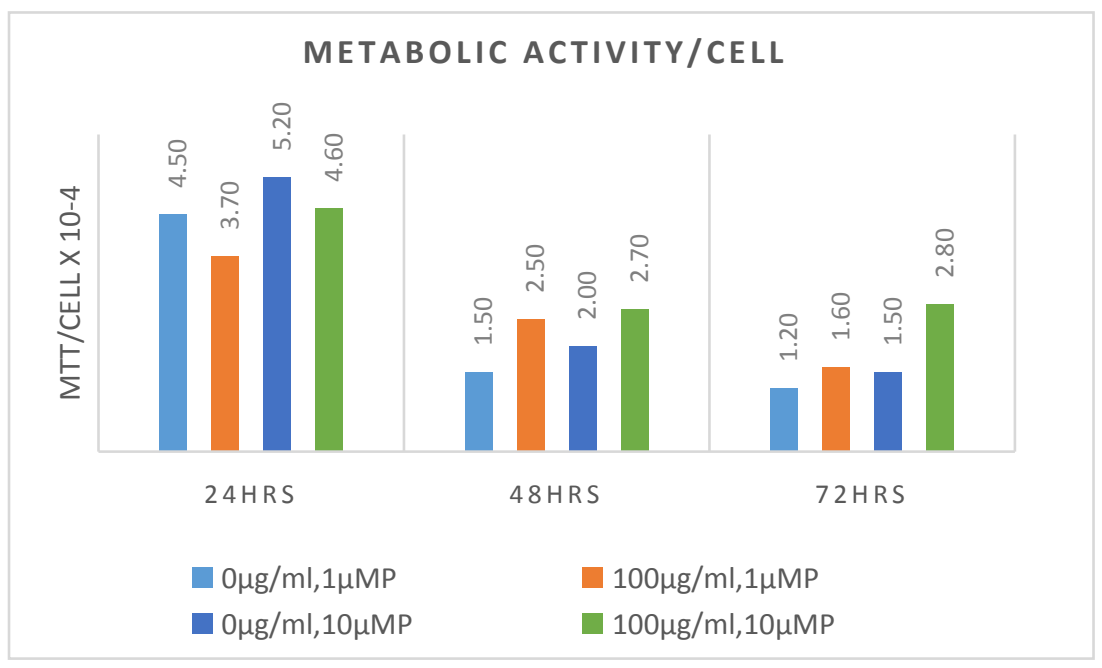

Figure S3. Metabolic activity/cell - Metabolic activity, measured using MTT assays (data shown in at $2 \mathrm{~A}$ and $\mathrm{B}$ ) is divided by proliferation, measured by cell counting (data shown in Figure $2 \mathrm{C}$ and D.) Per cell ratios for unexposed cells are higher than exposed cells at $24 \mathrm{hrs}$. This reverses at the next two timepoints; metabolic activity is lower per cell in the first 24 plus hours of exposure. 


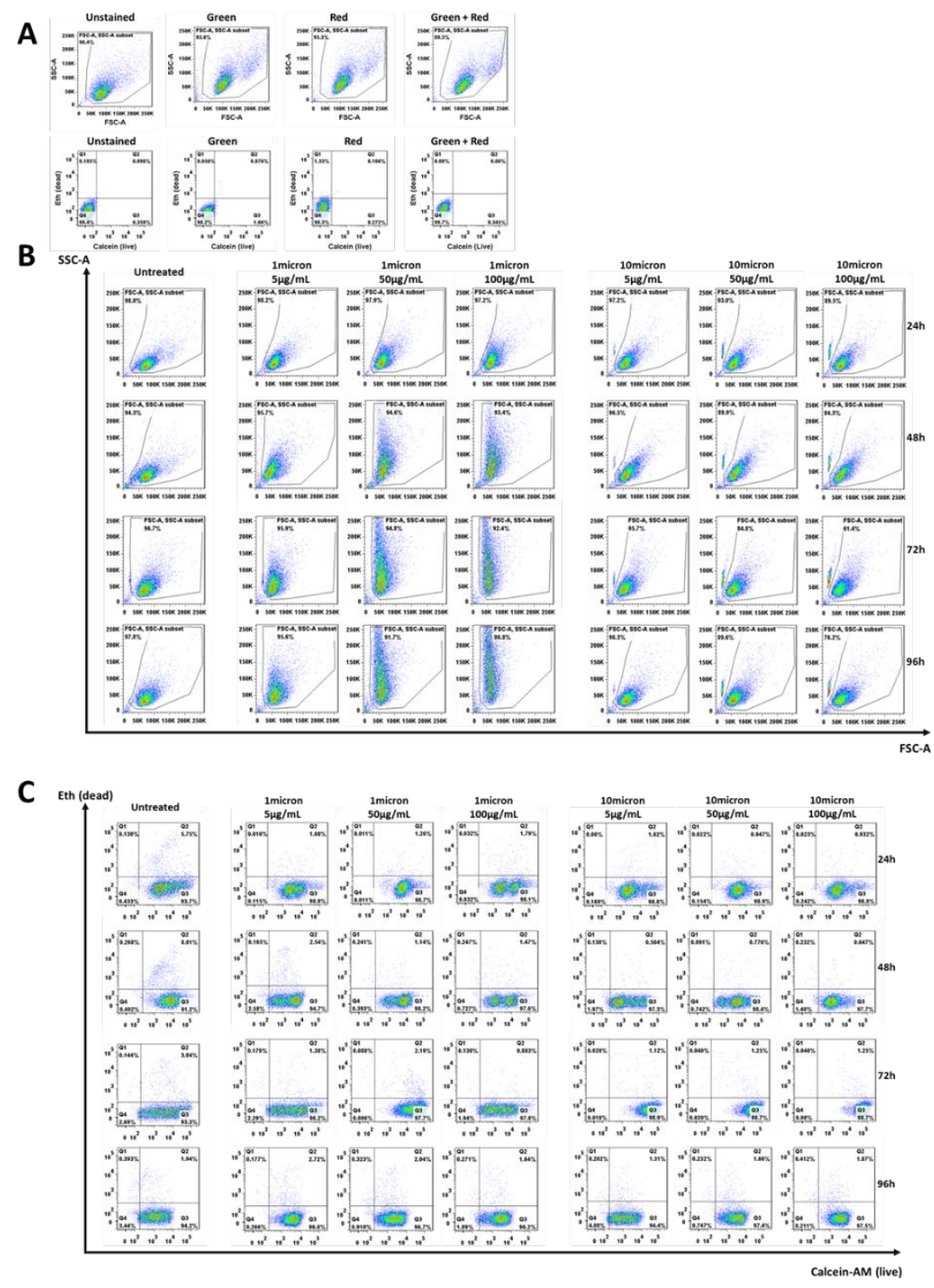

Figure S4. Flow cytometry controls and settings for Calcein A-M staining A) The fixed cell sample was run to adjust the voltage. The secondary IgG antibody staining samples of the fixed cells (the green, red, and green plus red) were run as the IgG isotype control (negative control) for the flow cytometry experiment. The top row presented the gating event when the samples were acquired. The bottom row presents the fluorescence signals. The X-axis and Y-axis designate the green and red fluorescent signals, respectively. B) The gating event for the live A549 cells following exposure to 1 and 10micron polystyrene microplastic particles at different time points and different concentrations. C) The viability of live A549 cells following exposure to 1 and 10micron polystyrene microplastic particles was analyzed with two-color flow cytometry with Calcein-AM (live marker) and ethidium homodimer-1 (Eth, dead cell marker). In the individual plots, each event is a fluorescently stained cell plotted with the intensity of Calcein stain on the Xaxis and intensity of ethidium stain on the Y-axis. Live cells were stained with Calcein plot in Q3. Percentages of the total cell population, as determined by total events measured, are shown for each quadrant - live cells plot in Q3; dead cells plot in Q2. 


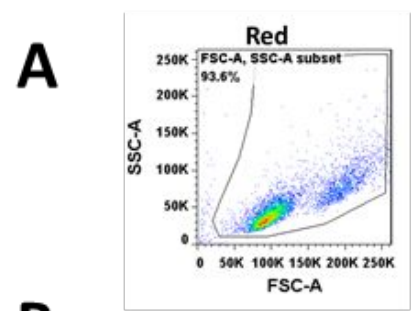

B

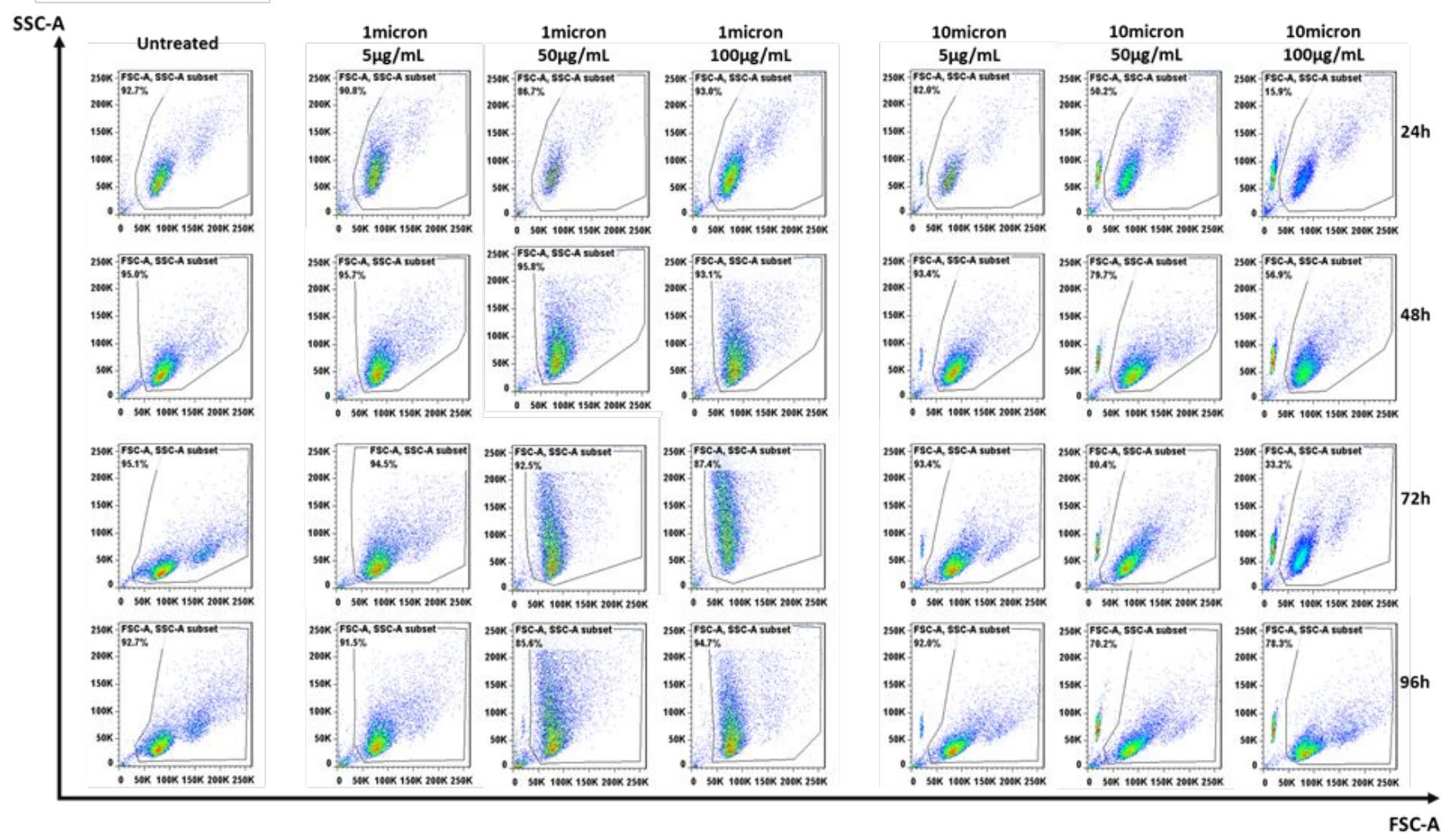

Figure S5. Flow cytometry controls and gate settings for Ki 67 antibody experiments. A) The fixed A549 cells with the red fluorescent only samples were run as the IgG isotype control (negative control) for the flow cytometry experiment. The gating of the acquired events was shown. B) The gating event for the fixed A549 cells following exposure to 1 and 10micron polystyrene microplastic particles at different time points and different concentrations. 


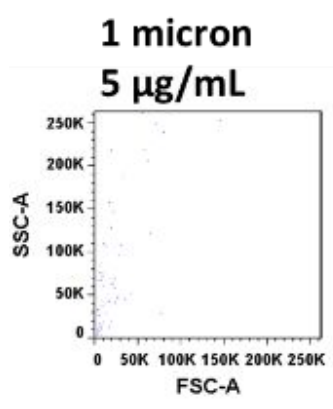

10 micron

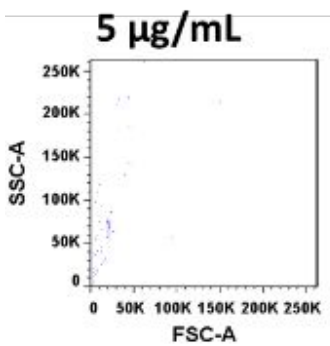

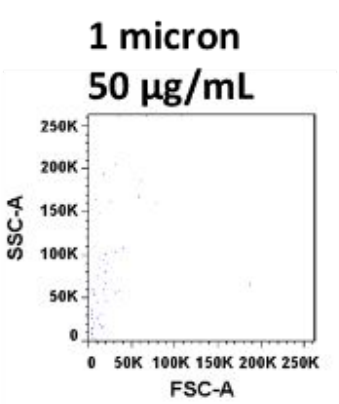

10 micron $50 \mu \mathrm{g} / \mathrm{mL}$

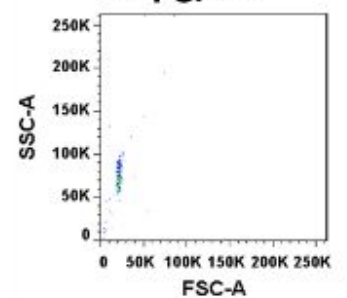

1 micron $100 \mu \mathrm{g} / \mathrm{mL}$

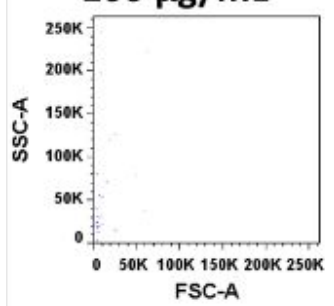

10 micron $100 \mu \mathrm{g} / \mathrm{mL}$

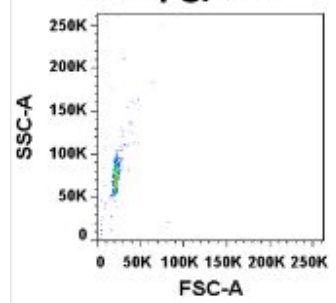

Figure S6. Flow cytometry of 1 micron and 10micron PS-MP particles alone. The 1 micron and 10 micron size of the microplastic particles were acquired at different concentrations using flow cytometry (See Table 1 for the associated particles/mL for each concentration). The 1 micron size was too small to be visible at concentrations used in this experiment, and only the 10micron particles appeared as a population from the sample acquired in this flow cytometry process, confirming what we saw in cells exposed incubated with microplastics. 

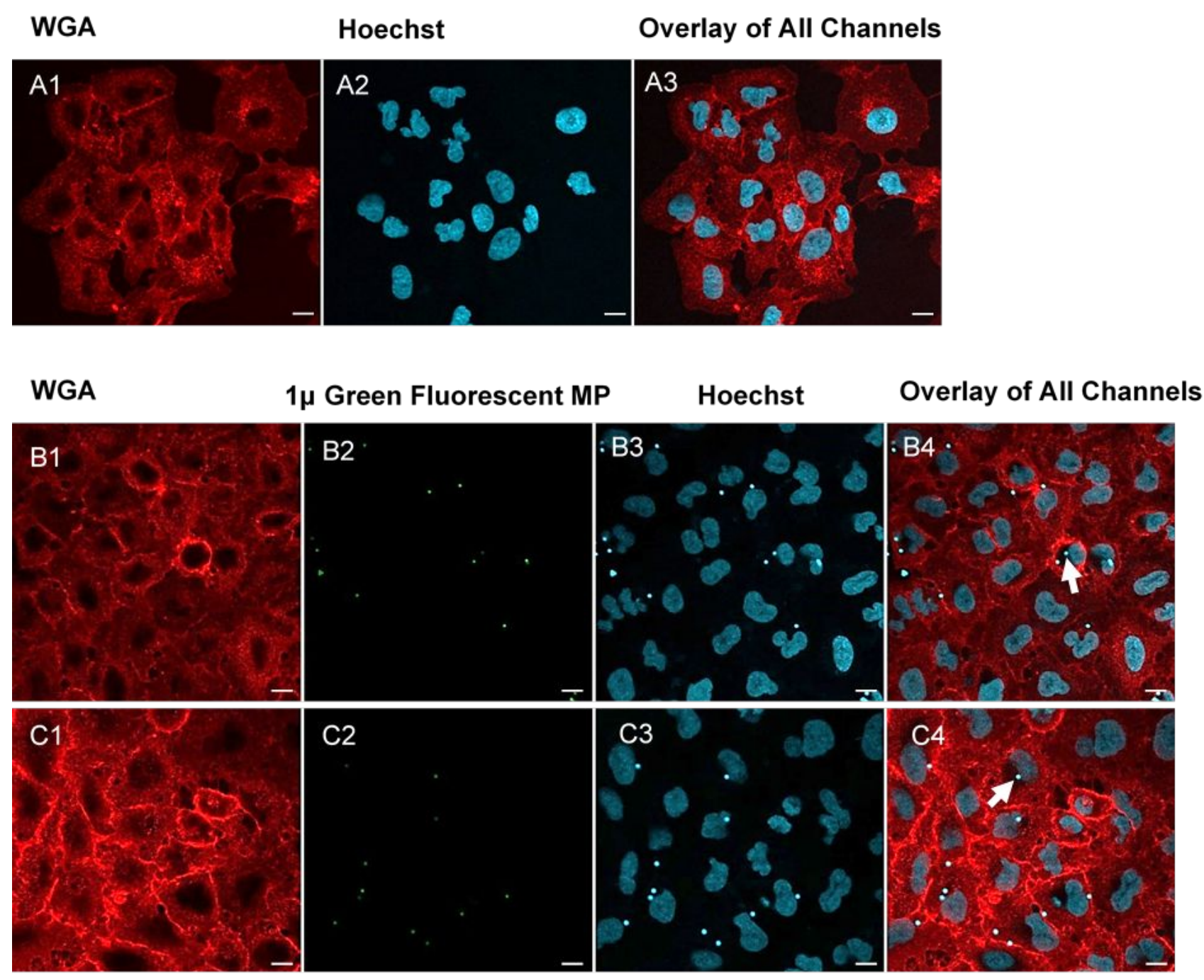

Figure S7. Additional confocal microscopy images of A549 cells exposed and unexposed to 1 micron green fluorescent PS-MPs. 3-D Z-Stack microscopy images of fluorescent channels and merged channels using confocal fluorescence microscope at $400 \mathrm{X}$ magnification. Cells were fixed using 4\% paraformaldehyde, cell membrane stained red Wheat Germ Agglutinin 594 Conjugate (WGA), and nucleus stained blue Hoechst-33342 Nuclear Stain (Hoechst). Panel A (Control Cells) and Panel B and Panel C (Cells with 1micron green fluorescent MP). A1, B1, and C1 are A549 cells with WGA-594. B2 and C2 show the 1micron green fluorescent MP. A2, B3, and C3 are A549 Cells with Hoechst. A3, B4 and C4 are A549 cells with overlay of all channels. B4 and C4 show internalization of 1micron fluorescent PS-MPs in A549 cells after 24hr exposure. White arrows point to internalized particles. Due to the bright fluorescence of 1micron green MP particles, particles also appear in blue channel. Scale bar is $50 \mathrm{micron}$. 


\begin{tabular}{|c|c|c|}
\hline Cytoskeletal Feature & Description & References \\
\hline Lamellopodia and Filopodia & $\begin{array}{l}\text { Figure } 2 \text { A-stained for actin. Top image shows } \\
\text { cell with lamellipodia, bottom image shows } \\
\text { retraction of lamellipodia and extrusion of } \\
\text { filopodia from remaining surface of } \\
\text { lamellipodia. }\end{array}$ & $\begin{array}{l}\text { 58) Mejillano, Marisan R., Shin- } \\
\text { ichiro Kojima, Derek Anthony } \\
\text { Applewhite, Frank B. Gertler, } \\
\text { Tatyana M. Svitkina, and Gary G. } \\
\text { Borisy. Lamellipodial Versus } \\
\text { Filopodial Mode of the Actin } \\
\text { Nanomachinery: Pivotal Role of } \\
\text { the Filament Barbed End. } 2004 . \\
\text { Lamellipodial Versus Filopodial } \\
\text { Mode of the Actin } \\
\text { Nanomachinery: Pivotal Role of } \\
\text { the Filament Barbed End. } 2004 .\end{array}$ \\
\hline \multirow[t]{2}{*}{ Filopodia } & Description & References \\
\hline & $\begin{array}{l}\text { Figure-2a. In migrating cells, filopodia } \\
\text { that are localized at the leading edge } \\
\text { probe the microenvironment and serve as } \\
\text { pioneers in cell protrusion }\end{array}$ & $\begin{array}{l}\text { 59) Mattila, P. K.; Lappalainen, } \\
\text { P. Filopodia: Molecular } \\
\text { Architecture and Cellular } \\
\text { Functions. Nature Reviews } \\
\text { Molecular Cell Biology. 2008, pp } \\
\text { 446-454.https://doi.org/10.103 } \\
\text { 8/nrm2406. }\end{array}$ \\
\hline \multirow[t]{3}{*}{ Focal Adhesions } & Description & References \\
\hline & $\begin{array}{l}\text { Figure } 2 \\
\text { immunofluorescent images of Human Vena } \\
\text { Saphena Cells stained for focal adhesions } \\
\text { (magenta) }\end{array}$ & $\begin{array}{l}\text { 61) C Buskermolen, A. B.; } \\
\text { Kurniawan, N. A.; C Bouten, C. } \\
\text { V. An Automated Quantitative } \\
\text { Analysis of Cell, Nucleus and } \\
\text { Focal Adhesion Morphology. } \\
\text { 2018.PlosOnehttps://doi.org/10 } \\
\text {.1371/journal.pone.0195201. }\end{array}$ \\
\hline & $\begin{array}{l}\text { Figure } 2 \text { Focal adhesions (FA) at edges and } \\
\text { underneath cell. Only FAs at edges can be } \\
\text { seen without fluorescent staining. }\end{array}$ & $\begin{array}{l}\text { 61) C Buskermolen, A. B.; } \\
\text { Kurniawan, N. A.; C Bouten, C. } \\
\text { V. An Automated Quantitative } \\
\text { Analysis of Cell, Nucleus and } \\
\text { Focal Adhesion Morphology. } \\
\text { 2018.PlosOnehttps://doi.org/10 } \\
.1371 / \text { journal.pone.0195201. }\end{array}$ \\
\hline \multirow[t]{2}{*}{ Microspikes } & Description & References \\
\hline & $\begin{array}{l}\text { Figure 1B: Shows an image of a single A549 } \\
\text { cell with both microspikes and filopodia } \\
\text { projexting from cell surface. }\end{array}$ & $\begin{array}{l}\text { 63) Ravindran, G.; Chakrabarty, } \\
\text { D.; Sarkar, A. Cadmium Toxicity } \\
\text { Causes Alteration in } \\
\text { MRNA Expression Pattern of } \\
\text { Rho-like Genes in Human Lung } \\
\text { A549 Cell Line. J. Cell Mol. } \\
\text { Biol. 2013, } 11 \text { (1-2), 13-20. }\end{array}$ \\
\hline
\end{tabular}

Table S3. Cytoskeletal and morphological features. This table outlines the different cytoskeletal and morphological features including: lamellopodia, filopodia, focal adhesions and microspikes that were observed in the A549 lung cells as well as in various other cell lines. These figures numbers in the Description are figures cited from the References, not from our experimental data. 